Siyag, P.R. 1998. The Afforestation Manual: Technology and Management. Indian Forest Service. ISBN: 81-901032-02. 632 p. Price: US $\$ 55.00+\$ 7.50$ postage. Contact: Executive (Marketing), TreeCraft Communications, 8A Kailashnagar, Jhotwara, Jaipur 302001 INDIA. Phone: +91 141340 333, Fax: +91 141519 282. Email: treecrft@jpl.dot.net.in

Smith, Wynet, et al. 2000. Canada's forests at a crossroads: an assessment in the year 2000. 114 p. Global Forest Watch, World Resources Institute, 10 G Street, NE, Washington, DC 20002 USA. Tel: +1-202-729-7694. Fax: +1202-720-7686. URL: http://www. globalforestwatch.org/

Stockdale, M.C., Corbett, J.M.S. 1999. Participatory inventory: a field manual written with special reference on Indonesia. OFI Tropical Forestry Paper No. 38. 383 p. ISBN 085074145 9. Price: ?25.00. Contact: Library and Information Service, Oxford Forestry Institute, University of Oxford, South Parks Road, Oxford OX1 3RB UK. Tel: +44-1865275082. Fax: +44-1865-275074. Email: library@plant-sciences.oxford.ac.uk URL: $\underline{\text { http://www.plants.ox.ac.uk/library }}$

\section{Special Subscription Prices for CIF/IFC Members}

Canadian Journal of Forest Research Subscription Rate for 2000

Printed Version Only

Regular price

CIF/IFC member's price

Printed Version Only

$\$ 80.00$ (plus $\$ 5.60$ GST) $=\$ 85.60$

Electronic Version Only

$\$ 72.00$ (plus $\$ 5.04 \mathrm{GST}$ ) $=\$ 77.04$

Printed + Electronic

$\$ 92.00$ (plus $\$ 6.44$ GST) $=\$ 98.44$

Environmental Reviews Quarterly Rate for 1999

Regular Price $\$ \$ 73.00$

CIF/IFC member's price

Printed Version Only

Electronic Version Only

$\$ 36.00$ (plus $\$ 2.52$ GST) $=\$ 38.52$

Printed + Electronic

$\$ 33.00$ (plus $\$ 2.31$ GST) $=\$ 35.31$

$\$ 42.00$ (plus $\$ 2.94$ GST) $=\$ 44.94$

van Etten, E.J.B. 1998. Mapping vegetation in an arid, mountainous region of Western Australia. Applied Vegetation Science 1(2): 189-200.

Wright, H.L., Adler, D. 2000. Proceedings of a workshop on humid and semihumid tropical forest yield regulation with minimal data. OP52. ISBN 085074 152 1. Price ? 8.00. Contact: Library and Information Service, Oxford Forestry Institute, University of Oxford, South Parks Road, Oxford OX1 3RB UK. Tel: +44-1865-275082. Fax: +44-1865-275074. Email: library@plant-sciences.oxford. ac.uk. URL: http://www.plants.ox.ac.uk/ library.

Source: "Forest Information Update" http://home.att.net/ gkLUND

\title{
FORESTRY EDUCATION / ÉDUCATION FORESTIÈRE
}

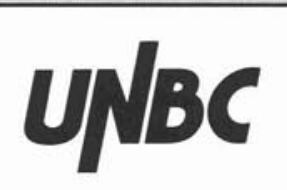

THE UNIVERSITY OF NORTHERN BRITISH COLUMBIA, Prince George, British Columbia. The Forestry Program offers a BSc in Natural Resources Management with a major in Forestry. A second major in Wildlife and Fisheries is offered jointly by the Forestry and Biology Programs. MSc and PhD degree programs in Natural Resources and Environmental Studies are also available. The undergraduate Forestry major is accredited by the Canadian Forestry Accreditation Board. The 4-year program of study includes a number of courses in common with the Wildlife and Fisheries major in such areas as forest biology, integrated resource management, resource planning, issues and ethics, and others. The intent is to provide a broad interdisciplinary foundation for specialization in the chosen major. Cooperative education opportunities are available. UNBC's Prince George campus is strategically located in the center of the province, amidst the province's major forest resource base, and thus has access to a wide range of forest types. The university is involved in a number of model and demonstration forests and has two research forests. We train the managers and scientists needed to effectively meet the demands for services and products from natural resources and still maintain a quality environment. The wise and sustainable use of our forest, fisheries, recreational and wildlife resources is a potent driver of our educational mission. Supported by programs in Resource Recreation/Tourism, Environmental Studies, Geography and Biology, the Forestry faculty conducts its research on issues that affect northern British Columbia and similar regions elsewhere in the world. Please direct enquiries to the Chair of the program, 3333 University Way, Prince George, BC, V2N $4 Z 9$. Telephone: (250) 960-6664, Fax: (250) 960-5539.
L'UNIVERSITÉ DE MONCTON. L'École de sciences forestières (ÉSF) de I'Université de Moncton offre un programme de baccalauréat et de maîtrise en sciences forestières. Le baccalauréat de cinq ans comporte plusieurs laboratoires en classe et en forêt et des stages en forêt et en milieu industriel. Le baccalauréat permet à l'étudiant(e) d'acquérir une formation dans les aspects environnementaux, biologiques, socioéconomiques et technologiques reliés à la foresterie.

II vise aussi à inculquer chez l'étudiant(e) une vision de l'aménagement intégré des ressources et du développement durable des forêts. Les diplômé(e)s sont admissibles aux différentes corporations professionnelles canadiennes. Le baccalauréat est aussi offert en régime coopératif, programme qui permet d'intégrer étroitement la formation universitaire à l'expérience pratique du marché du travail. II implique une alternance entre les sessions d'études et de stages rémunérés effectués dans diverses organisations partout au Canada et même à l'étranger. L'ÉSF est située sur le campus d'Edmundston de l'Université de Moncton. À environ quarante kilomètres du campus, l'ÉSF gère une Forêt expérimentale de 830 hectares. Ce territoire est réservé pour les travaux pratiques des étudiant(e)s, la recherche, la récréation et la vulgarisation forestière. Les étudiant(e)s sont admissibles dès la fin de leurs études secondaires. Ceux et celles possédant une formation collégiale peuvent obtenir des équivalences de cours. Pour plus de renseignements:

École de sciences forestières, 165, boulevard Hébert, Edmundston, N.-B., E3V 2S8.Téléphone:1-800-561-9064, (506)737-5068. Fax:(506)737-5373. Courriel: clajoie@ cuslm.ca. Sitelnternet: http://www.cuslm.ca/ 


\section{(C) \\ COLLEGE}

OFTHE

NORTH

ATLANTIC
COLLEGE OF THE NORTH ATLANTIC, Corner Brook Campus, P.O. Box 822, Corner Brook, NF A2H $6 \mathrm{H} 6$.

The College of the North Atlantic offers a group of programs in the natural resources technology field. The two-year Forest Resources Technician diploma program shares a common first year with the Fish and Wildlife Technician program. The Forest Resources program includes a balance of class, lab and crew fieldwork experiences in forest utilization, protection, improvement, and management. Students are exposed throughout the program to the use of computer technology in general and to GIS software in particular. A wide range of specific technical topics is included with the trend towards integrated management of our natural resources. The Forest Resources program is internationally recognized by the Society of American Foresters, and nationally accredited by the Canadian Council of Technicians and Technologists. For more information, call (709) 637-8517; fax (709)637-8645; or write to; Forest Resources Technician program, Corner Brook Campus, College of the North Atlantic, P.O. Box 822, Corner Brook, NF A2H $6 \mathrm{H} 6$

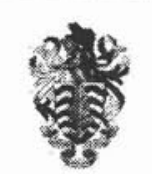

The University of Toronto, Toronto, Ontario. The Faculty of Forestry at the University of Toronto offers M.Sc.F. and $\mathrm{Ph} . \mathrm{D}$. graduate research programs, particularly in biological pest control, tree physiology, fire management systems, forest management and conservation, community forestry, urban entomology, forest soils and tree nutrition, soil conservation, land reclamation, forest ecology and wood science and forest products. The Faculty also offers a 16-month Master of Forest Conservation (M.F.C.) degree program which focusses strongly on field work and global forest conservation, with an international field camp. The Faculty also participates in collaborative programs in environmental studies and environmental toxicology with the Institute for Environmental Studies.

The Faculty welcomes students from diverse backgrounds: forestry, agriculture, biology, botany, environmental studies, engineering, mathematical and computer science, physical and social sciences, and zoology. Located in the new Earth Sciences Centre at the University of Toronto, the Faculty of Forestry has well-equipped computer, research and teaching laboratories. Direct enquiries to Faculty of Forestry, University of Toronto, Earth Sciences Centre, 33 Willcocks Street, Toronto, Ontario M5S 3B3. (Phone) 416-978-6152; (fax) 416-978-3834; (email) gradprog@ forestry.utoronto.ca; (WWW) http://www.forestry.utoronto.ca.

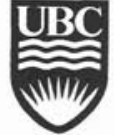

THE UNIVERSITY OF BRITISH COLUMBIA. The Faculty of Forestry offers four-year degree programs in Forest Resources Management, Forest Operations, Forest Sciences, Wood Products Processing, and Natural Resources Conservation. The Management and the Operations programs are fully accredited by the Canadian Forestry Accreditation Board. Graduates of these two programs are eligible for registration as Forestersin-Training in the Association of B.C. Professional Foresters. Each degree program has required courses designed to enhance knowledge as well as increase technical skills. The Faculty also offers programs leading to MSc, MASc, MF, and PhD degrees in most fields of Forestry and Wood Science. The UBC campus is surrounded by a large forested regional park which is frequently used as an outdoor classroom for forestry labs. In addition, the Faculty of Forestry maintains two research forests: the Malcolm Knapp Research Forest in Maple Ridge and the Alex Fraser Research Forest near Williams Lake. The Faculty of Forestry supports two specialized research centres: the Centre for Applied Conservation Biology and the Centre for Advanced Wood Processing.

Direct enquiries to the Faculty of Forestry, Forest Sciences Centre, 2005-2424 Main Mall, Vancouver, BC V6T 1Z4. Telephone (604) 822-2727. Fax (604) 822-8645. E-mail: forrecep@ interchg.ubc.ca. Additional information is available on the Faculty of Forestry Home Page http://www.forestry.ubc.ca.

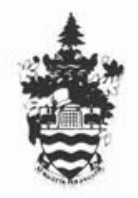

LAKEHEAD UNIVERSITY. The Faculty of Forestry and the Forest Environment offers the following programs: Honours Bachelor of Science of Forestry (H.B.Sc.F.), Honours Bachelor of Environmental Studies (Forest Conservation) (H.B.E.S.), Bachelor of Environmental Studies (B.E.S.), Master of Science in Forestry (M.Sc.F.), Master of Forestry (M.F.), Diploma in Integrated Resources

Management. The H.B.Sc.F. provides the academic requirements for qualifying for membership in the Professional Foresters Association of Alberta, British Columbia, New Brunswick, Ontario and Quebec. The variety of forestry and science courses provided over four years prepare the graduate for a wide range of resource oriented positions. Students have the option of taking a five year Co-op degree. The H.B.E.S. and B.E.S. degrees prepare the student in forest resource oriented environmental studies. The M.Sc.F. program is research oriented and requires the completion of a thesis on one facet of forestry. Advanced skills in forest decision making are emphasized in the M.F. program. Students must complete a project report. The M.F. may also be obtained through our distance education program. Our diploma program provides academic study and practical field training in integrated resource management to prepare students for employment in resource oriented fields. Transfers from diploma programs to the H.B.SC.F. program are possible. Further information about our degree and diploma programs may be obtained by writing to the Faculty of Forestry and the Forest Environment, Lakehead University, Thunder Bay, Ontario, P7B 5E1. Telephone: (807) 343-8623. Fax (807) 343-8116. e-mail mbeck@sky.lakeheadu.ca. Information is also available on our website: http://www.lakeheadu.ca/forwww/forestry.html.

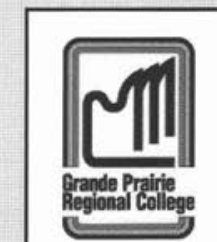

GRANDE PRAIRIE REGIONAL COLLEGE, Bachelor of Applied Forest Resource Management Program, Grande Prairie, Alberta - The forest industry has indicated a hiring preference for graduates with practical experience. Our unique four-year degree program, developed in partnership with the forest industry, provides that experience. The program emphasizes applied learning through six semesters of academic course work on campus, and two semesters of practicum at an industry site. The practicum, which carries some financial assistance, covers the range of skills essential to a forestry graduate. With Grande Prairie and vicinity supporting a number of major forest industries, Grande Prairie Regional College is ideally situated to host this Applied Degree program. Upon completion of the program, you will be prepared for employment in a broad range of occupations in forestry. For further information, contact the Registrar, Grande Prairie Regional College, 10726-106 Avenue, Grande Prairie, Alberta, T8V 4C4. Phone: 1-888539-GPRC. Website: www.gprc.ab.ca/courses_and_programs/forestry E-mail: lynn@gprc.ab.ca.

\section{$\mathbb{N} \sqrt{1 / 4}$ \\ THE NORTHERN ALBERTA THE NORTHERN ALBERTA
INSTITUTE OF TECHNOLOGY} year of the program begins with a five-
week field camp, with the balance of the year taught at the main campus in Edmonton. The second year is delivered at the Environmental Training Centre in Hinton, Alberta. There is a balance between classroom/ laboratory and field work in both first and second year. Applicants require the equivalent of an Alberta General High School Diploma or equivalent including English 30 or 33 , Mathematics 30 or 33, plus two of Biology 20 , Chemistry 20 and Physics 20 , with preference given to applicants with 30-level sciences, St. John Ambulance Standard First Aid Certificate and CPR heartsaver. For further information contact the Registrars office at 1-800-661-4077 


\section{STPRTAGE 13. COLLEGE}

Portage College (formerly Alberta Vocational College - Lac La Biche)

The Forest Technician program is a one year certificate program designed to prepare personnel in the practical and technical skills needed to work in the forest industry. The program consists of classroom lectures and field training using current industry practices. The program stays current through close liaison with industry and government and receives input on curriculum and field activities from a Forestry Advisory Committee. Subject areas include: Communications, Equipment and Safety, Silviculture, Fitness, Outdoor Skills, Work Experience, Forest Protection, Forest Management, Forest Measurements, Harvesting, and Wood Utilization. Employment opportunities exist within all areas of the forest sector. Graduates have worked with forestry consultants, forestry companies, and with the Department of Environmental Protection, Lands and Forest Services Branch. Graduates have also worked as independent forestry contractors, and have branched off into other industries that are directly associated with forestry land management. For further information contact: Admissions, Portage College, P.O. Box 417, Lac La Biche, Alberta TOA 2C0, Phone (780) 6235551 or toll free (Alberta only) 310-0000 then enter 623-5551.

ENVIRONMENTAL TRAINING CENTRE, Hinton, Alberta. The Environmental Training Centre (ETC) is an in-service training centre operated by Alberta Environment. The Centre offers a number of natural resource management courses including a unique and highly-advanced fire control program which uses laserdisc technology for fire simulations. Also an array of Forest Management programs including AAFMI Modules. The Centre houses the headquarters of the Foothills Model Forest. The second year of the Forest Technology program of the Northern Alberta Institute of Technology is presently taught at the Centre. Members of the forest industry and other cooperating agencies are welcome to register to attend any ETC course. For further information, contact Director, Environmental Training Centre, 1176 Switzer Drive, Hinton, Alberta T7V 1V3. Phone: 780865-8200. Fax: 780-865-8266. E-mail: envtrain @env.gov.ab.ca

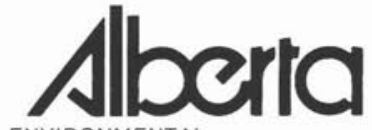

ENVIRONMENTAL

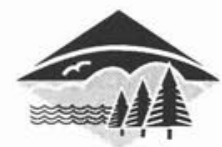

Algonquin College, Pembroke, Ontario. The Forestry Technician Diploma Program at Algonquin College in Pembroke, Ontario is an intensive 50 -week program of study that utilizes the nearby forests of Algonquin Park and the Ottawa Valley. The unique location offers access to the federal Petawawa Research Forest, and agencies such as the Algonquin Forestry Authority, the Ministry of Natural Resources, and a diverse group of forest companies. An emphasis on practical field experience brings theoretical principles into perspective. Graduation can lead directly to a career in natural resources management or to further education, including the multi-discipline, post-graduate Environmental Studies Program offered through Distance Education at Algonquin College, Ottawa. Admission requirements for Algonquin's Forestry Program are Ontario Secondary School Diploma at or above the general level (or equivalent) with English and Math at the Grade 12 General level; or mature student status. For further information, contact Admissions at (613) 735-4708 or the Forestry Program Co-ordinator, F. Knaapen at (613) 735-4741 (e-mail: knaapef@algonquincollege.com).

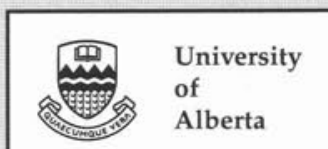

THE FACULTY OF AGRICULTURE, FORESTRY AND HOME ECONOMICS offers eight undergraduate Bachelor of Science programs, including degrees in Forestry, Forest Business Management, and Environmental and Conservation Sciences. In these programs, students may major in forest management; forest business management; conservation biology; environmental economics and policy; human dimensions of environmental management; or land reclamation. The Forestry and Forest Business Management degrees are designed to meet the CFAB standards for professional forestry registration. The Faculty prides itself on being a leader in the education and training of resource managers from a holistic and integrated perspective. For more information call the Office of the Dean at (780) $492-4933$ or 1-800804-6417 (in Western Canada) or visit the web site at www.afhe.ualberta.ca.

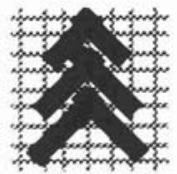

FACULTY OF FORESTRY \& ENVIRONMENTAL MANAGEMENT, University of New Brunswick, Fredericton, NB. Degree programs in Forestry (BSCF) and Forest Engineering (BSCFE) after grade XII or Quebec High School Leaving Examinations. The BsScF program includes a blend of biophysical, social, and management sciences; electives can lead to minors in Computer Applications, Economics, Business, Wildlife (expandable to give Wildlife Biologist certification by the Wildlife Society), Parks and Wilderness, Environmental Studies, Wood Products or Forest Science. BScFE graduates are qualified to deal with engineering, implementation, and production aspects of management plans that are ecologically sound an economically feasible. Both programs include a Professional Experience Term. Graduate programs leading to MScF of MF degrees are available in forest soils, hydrology and meteorology, ecology, management, economics, pathology, entomology, information systems, conservation, wildlife management, tree physiology, and wood science. MScFE and MFE programs are available in environmental studies, operations management, harvesting, wood supply, site preparation and stand establishment, geotechnical engineering, roads and transportation, industrial engineering, machine design, wood products and wood engineering. $\mathrm{PhD}$ programs are available in the same fields. Enquiries should be directed to the Assistant Dean, P.O. Box 44555, E3B 6C2, or phone (506) 453-4501.

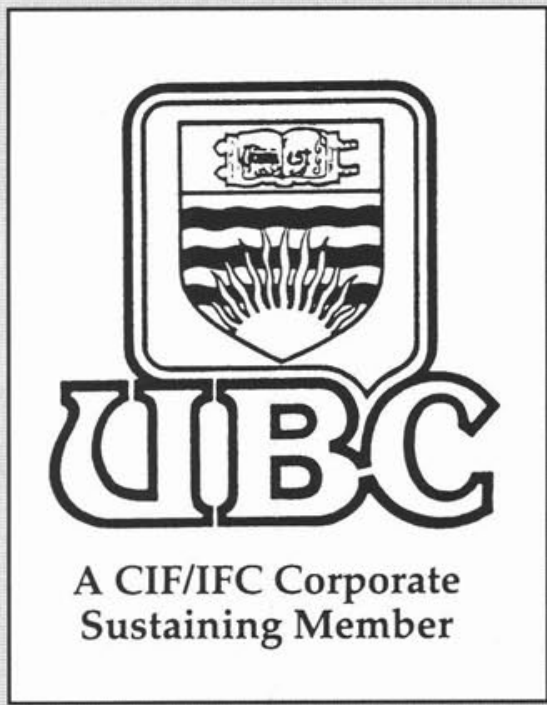

